\title{
Література:
}

1. Горбов А. Режисура видовищно-театралізованих заходів: посібник. Фастів: Поліфаст, 2004. 264 с.

2. Новер Ж.-Ж. Письма о танце. Пер. с фр. под ред. А. А. Гвоздева. Санкт-Петербург : Лань; Издательство Планета музыки, 2007. 384 с.

3. Плахотнюк О. Героїко-патріотична спрямованість сучасної хореографії в рамках фестивалю "Сурми звитяги". Вісник Начіональної академії керівних кадрів культури і мистеитв. 2020. № 1. С. 97-103.

4. Формування базових компетентностей учнів загальноосвітньої школи у системі мистецької освіти / Л. Масол, Н. Митропольська, В. Рагозіна та ін. за наук. ред. Л. Масол. Київ : Педагогічна думка, 2010. 232 c.

\section{DOI https://doi.org/10.30525/978-9934-26-178-7-25}

\section{ПРОБЛЕМИ ГЛОБАЛІЗАЦІї ТА КУЛЬТУРНОЇ ІДЕНТИЧНОСТІ: ЗА ОСТАННЬОЮ СТАТТЕЮ О. П. БЛАВАТСЬКОї}

\author{
Моргунова А. Ф. \\ завідуюча відділом «Музейний иентр О. П. Блаватської та ї̈ родини» \\ Дніпропетровський національний історичний музей \\ імені Д. І. Яворницького \\ м. Дніпро, Україна
}

Світові глобалізаційні процеси мають вплив на всі сфери життєдіяльності людства. Знецінення духовних і моральних ідеалів, культурного надбання людства на тлі процесів глобалізації призводить до знищення національних культур, та низки інших проблем, у в тому числі проблем соціальних та екологічних. Ці питання, а також можливі шляхи щодо їх вирішення були розглянуті наприкінці XIX століття О. П. Блаватською. Духовна криза в світі глобалізації, витоки якої розглядала О. П. Блаватська наразі продовжується. Мислителі та вчені XX-XXI століття так само опікуються проблемами переваги цивілізації над культурою, падіння духовного і морального рівня людини в сучасному суспільстві, нерозуміння глибинного та нерозривного зв'язку людини з природою, серед них: В. Вернадський, М. Бердяєв, Е. Фромм [4], [1], [7]. 
У щоденниках О. I. Реріх $\epsilon$ згадка про останню статтю О. П. Блаватської: «Остання думка великої жінки була про мистецтво» [7, с. 37]. Стаття називається «Цивілізація, смерть мистецтва і краси» ${ }^{1}$. Надрукована вона в травні 1891 року.

Ця стаття викликає інтерес не тільки тому, що виявилася останньою написаною і надрукованою статтею О. П. Блаватської, вона важлива 3 точки зору iіi актуальності, в ній розглядаються найважливіші загальносвітові проблеми сучасності:

- Проблема зникнення національних культур під натиском західної цивілізації.

- Тенденції занепаду справжнього мистецтва; пріоритет кількості творів мистецтва за рахунок їх якості в гонитві за наживою.

- Варварське ставлення до природи, екологічні проблеми.

- Відсутність духовності і втрата моральних цінностей в суспільстві.

Чому саме О. П. Блаватська розглядає проблеми культури та мистецтва стає зрозумілим, якщо звернутися до іiі біографії. Вона виросла в родині, в якій цим темам відводилася значна роль. Олена Блаватська, успадкувавши здібності від бабусі О. П. Фадєєвої і мами О. А. Ган, чудово малювала і грала на фортепіано. Перші уроки гри О. П. Блаватській давала мама, «проте пізніше запросила професійних вчителів, тому що учениця виявилася вельми здатною» [5, с. 33]. Що стосується музичної освіти О. П. Блаватської, то вона пройшла не тільки домашнє навчання. «О. П. Блаватська згадує про декілька уроків у «старого Мошелеса», відомого піаніста і композитора ... Декілька років по тому вона навіть дала кілька концертів в Англії і в інших європейських країнах» [5, с. 66]. Музична тема супроводжувала О. П. Блаватську все життя. У багатьох статтях і в художніх творах вона пише про музику. Розуміючись не тільки на європейській музичній традиції, в своїх роботах вона розповідає і про музику стародавнього Єгипту [4, с. 590], і про особливості східної музики, зокрема індійської. О. П. Блаватська розповідає, що «в Індії музика була вже відома i приведена до системи, коли сучасні нації жили ще на заході Свропи як дикі племена» [3, с. 268]. Ця цитата 3 книги перекликається з роздумами в статті «Цивілізація, смерть мистецтва і краси», яка починається 3 розповіді відомого угорського скрипаля М. Ремені про його концерти в Японії і про гнітюче враження, яке справило на нього прагнення японської знаті і культурної еліти виглядати по-европейські. О. П. Блаватська вивчала не тільки стародавні філософські та релігійні

1 Переклад статті виконаний автором тез 102 
вчення, але й культурну спадщину стародавніх цивілізацій. Її роботи наповнені описами культурних та історичних цінностей тих місць, де вона бувала. О. П. Блаватська здійснила не одну кругосвітню подорож. Саме тому ii міркування, про самобутність національних мистецтв $\mathrm{i}$ культур, не абстрактні, а мають глибоке підгрунтя. У статті О. П. Блаватська розмірковує про те, наскільки прекрасні й неповторні древні культури і як важливо зберегти їх надбання.

Вона закликає представників самобутніх національних культур не жертвувати «своєю індивідуальністю заради порожньої видимості та тіні» [8]. Розуміючи, що «давно пора щось робити в цьому напрямку. В іншому випадку, старе мистецтво і художні твори, все оригінальне i унікальне дуже скоро зникне. Національні костюми і освячені віками звичаї, все прекрасне, художнє і гідне збереження вже швидко зникає 3 поля зору» [8].

О. П. Блаватська вказувала на витоки проблем занепаду національних культур більше, ніж століття тому. Власне мова йде про культурну ідентичність. Будь-яка етнічна культура формує свою неповторну культурну спільноту, морально-етичні норми суспільного життя, цінності, ідеали. Відмова від своїх культурних традицій призводить до уніфікації культур і це одна з найбільших проблем процесу глобалізації. О.П.Блаватська підводить нас до думки, що все розмаїття культурних, етнічних, духовних надбань людства необхідно, не тільки зберігати, але й розвивати. Бо знецінення духовних і моральних устоїв, звичаїв $\mathrm{i}$ народних святинь призводить до деградації, і по суті до знищення народів як таких.

О. П. Блаватська застерігає й від національної зверхності. «Матеріалізм і байдужість до всього, крім егоїстичного усвідомлення багатства і влади, а також надмірне вигодовування національного i особистого марнославства, поступово привели народи і окремих людей до майже повного забуття духовних ідеалів, любові до природи i правильної оцінки речей» [8].

Справжнє мистецтво може існувати лише в суспільстві, де духовні цінності, високі релігійні та етичні норми - це не порожні звуки, а основа соціуму. Але якщо все підпорядковано лише комерційним міркуванням, то шедеври мистецтва неминуче перетворяться в звичайні зразки. «Ми чуємо, що галереї живопису і скульптури з кожним роком стають все біднішими за якістю, хоча і багатше за кількістю. Вважається, що, хоча існує безліч звичайних творів, переважає величезний дефіцит видатних картин і скульптур». Бо «головна турбота - це не створення предметів мистецтва, а їх швидкий продаж і отримання прибутку» [8]. 
Відкидання попереднього культурного досвіду, ще одна з проблем глобалізації з точки зору культурної ідентичності. За передачу цього досвіду і його збереження ратує О. П. Блаватська.

Техногенна цивілізація сприймає природу виключно як джерело енергетичних і іншого роду матеріальних ресурсів. Суспільство споживання, яке сформоване на сьогодні, мало турбують наслідки такого безрозсудного варварського відношення до природи. О. П. Блаватська бачила ці проблеми ще у їх витоків і застерігала своїх сучасників від таких небезпечних тенденцій. «Мистецтво і геній, істина i справедливість щодня приносяться в жертву ненаситній мамоні цього століття - жадобі наживи. Штучне всюди замінює природне, неправдиве замінює істинне. ...Стародавні цивілізації ніколи не жертвували Природою заради спекуляцій, але, вважаючи ії божественною, шанували iii природну красу, створюючи твори мистецтва, які наша сучасна електрична цивілізація ніколи не змогла б зробити навіть уві сні» [8].

О. П. Блаватська піднімає в своїй статті й питання екології. Наскільки злободенно зараз звучать іï слова: «Внаслідок звитяжного маршу i вторгнення цивілізації Природа, а також людина і етика приносяться в жертву і швидко стають штучними. Змінюється клімат, і скоро зміниться обличчя всього світу». [8].

Червоною ниткою через усі роботи О. П. Блаватської проходить думка про першорядну вагу духовної складової будь-якої діяльності як окремої людини, так і суспільства в цілому. В. І. Вернадський, автор теорії «ноосфери», писав про те, що створює ноосферу нова форма біогеохімічної енергії, яку він називав «енергією людської культури» [5, c. 226]. I «якість» цієї енергії, безсумнівно, залежить від того, що обирає людське співтовариство: альтруїзм, етику, духовні цінності; або егоїзм, падіння моралі і цінності матеріальні. О. П. Блаватська розглядає одну 3 основних складових поняття Культури - Мистецтво. Адже саме через мистецтво, торкаючись до краси, людина може знайти розуміння Вищого джерела, Вищих духовних ідеалів. Про це також писала O. I. Реріх: «Мистецтво, в усіх його проявах і у всіх умовних формах, завжди буде початком духовним, що будить спрямування до краси, до Вищого, і в цьому його головне і найбільше значення» [6, с. 458].

Процес об'єднання необхідний людству, проте умовами об'єднання повинні бути повага до національних і культурних особливостей i відмінностей, збереження i примноження духовних i моральних загальнолюдських цінностей. Оскільки ноосфера, про яку вже йшлося, явище глобальне і має на увазі погляд на людство як на єдиний організм, ми повинні з однаковою повагою і турботою ставитися до всіх його частин, не розділяючи їх на важливі і не важливі. Цивілізація і культура 104 
поняття не тотожні, тому завдання людства через розвиток і розквіт національних культур привести нашу цивілізацію до Культури, тобто до «культу Світу» (як перекладається це слово).

\title{
Література:
}

1. Бердяев Н. А. О назначении человека. Москва. 2010. 478 с.

2. Блаватская Е. П. Из пещер и дебрей Индостана. Москва. 2007. $832 \mathrm{c}$.

3. Блаватская Е. П. Разоблаченная Изида. Москва, Санкт-Петербург. 2007. 1360 с.

4. Вернадский В. И. Биосфера и ноосфера. Москва, 1989. 261 с.

5. Крэнстон С. Е. П. Блаватская. Рига. 1999. 736 с.

6. Рерих Е. И. Письма. / 1919-1933. Москва. 2011. Т.1. 496 с.

7. Рерих Е. И. Листы дневника. / 1924-1925. Москва. 2011. T. 2. $400 \mathrm{c}$.

8. Фромм Э. Иметь или быть? Москва. 2004. 384 с.

9. Blavatsky H. P. Civilization, the death of art and beauty. Lucifer. 1891. № 45. P. 177-186. URL: https://theosophy.world/ (дата звернення: 19.11.21)

\section{DOI https://doi.org/10.30525/978-9934-26-178-7-26}

\section{ВВЕДЕННЯ ДО ПРОБЛЕМАТИКИ КОСТЮМНОГО ЕНВАЙРОНМЕНТУ ТА ЙОГО ГУМАНІСТИЧНІ ЦІННОСТІ}

\author{
Токар М. I. \\ кандидат мистецтвознавства, доцент, \\ доцент кафедри аудіовізуального мистецтва, перший проректор \\ з науково-педагогічної роботи \\ Харківська державна академія дизайну і мистеитв \\ м. Харків, Украӥна
}

Тематика екології та вторинної переробки матеріалів 3 метою подальшого їхнього використання залишається досить актуальною в сучасному мистецтві. Створені таким чином арт-об'єкти вирізняються 3-поміж інших, особливо такі, що мають подвійну адресацію, а саме спрямовані безпосередньо на глядача та на його середовище задля зміни останнього. Такі зразки сучасного мистецтва дістали на сьогодні назву «енвайронмент». 